\title{
The Stability and Growth Pact - Theorizing a Case in European Integration*
}

\author{
MARTIN HEIPERTZ \\ European Central Bank \\ AMY VERDUN \\ University of Victoria
}

\section{MPIfG Journal Article}

Martin Karl Georg Heipertz, Amy Verdun: The Stability and Growth Pact: Theorizing a Case in European Integration. In: Journal of Common Market Studies 43(5), 985 - 1008 (2005). Wiley-Blackwell

The original publication is available at the publisher's web site: http://dx.doi.org/10.1111/j.1468-5965.2005.00605.x

The MPIfG Journal Articles series features articles by MPIfG researchers and visiting scholars published in peer-reviewed journals. Max Planck Institute for the Study of Societies (MPIfG) Cologne | www.mpifg.de

\begin{abstract}
This article looks at the Stability and Growth Pact (SGP) as a case study in European integration. Applying the theoretical lenses of various European integration approaches (intergovernmentalism, domestic politics, neofunctionalism and an 'expertocratic' approach) it seeks to explain the creation of the SGP as well as its subsequent implementation. The findings show that these approaches are able to illuminate different parts of the process. The article thus argues that only an eclectic combination of the approaches provides a satisfactory theoretical explanation of the SGP as a fundamental element of the rules-based economic and monetary union (EMU) regime.
\end{abstract}

\section{Introduction}

The Stability and Growth Pact (SGP) offers an interesting puzzle for scholars of European integration. Created in 1997, it was set up to complement the then

\footnotetext{
* Most of the research for this article was conducted when the authors were based at the Max Planck Institute for the Study of Societies, Cologne, and at the Institut d'Etudes Politiques (Sciences-Po Paris). The authors wish to acknowledge generous research funding from the Max Planck Society, from the Deutsche Akademische Austauschdienst (DAAD), and from the Social Sciences and Humanities Research Council of Canada (grant number 410-2002-0522). Earlier versions of the paper were presented at the Second PanEuropean Conference on EU Politics, ECPR Standing Group on the European Union, Bologna, 24-26 June 2003, at the CERI Faculty Seminar, Sciences Po, Paris, 26 April 2004, at the Institute of European Studies, University of Toronto on 28 October 2004 and at the Institute of European Studies, Carleton University, Ottawa, on 29 October 2004. The authors wish to thank participants at these meetings for useful comments and suggestions. Special thanks go to Joan DeBardeleben, Nicolas Jabko, Jeffrey S. Kopstein, Patrick Legales, Kathleen R. McNamara, Louis W. Pauly, Fritz W. Scharpf, Wolfgang Streeck and two anonymous referees. The views expressed are solely those of the authors and do not necessarily represent the views of institutions for which they work or have worked.
} 
approaching creation of economic and monetary union (EMU). The Treaty establishing a European Community (TEC), signed at Maastricht in 1992, listed clear criteria for joining EMU but contained only general provisions to secure the maintenance of low budgetary deficits once the euro was introduced (for an analysis of the origins of the SGP, see Heipertz and Verdun, 2004a). The SGP represents a specification of these rules. ${ }^{1}$ Member States are to keep their budgetary deficits below 3 per cent of gross domestic product (GDP) or eventually face sanctions. The puzzle is, why did sovereign Member States agree to submit themselves to such far-reaching rules? The SGP has become interesting for scholars beyond its initial creation as it attracted controversy after the Council of Ministers of Economic and Financial Affairs (Ecofin) in November 2003 decided to suspend the pact temporarily. This decision was scrutinized by the European Court of Justice, and led to a painstaking reform exercise in the first half of 2005.

Political scientists have applied various theoretical approaches to explain the phenomenon of European integration. Using four of these approaches, this article asks the question, how can they explain the creation of the SGP and its (non-)application? The four most promising theoretical approaches are presented below. The conclusion is that only an eclectically constructed combination of their explanations provides a satisfying account. ${ }^{2}$ Two of the European integration approaches chosen derive from international relations (IR) (i.e. intergovernmentalism and neofunctionalism); the other two approaches (i.e. domestic politics and ideational approaches) draw on comparative political economy (CPE). Together they provide a thorough understanding of the creation and demise of the SGP. They each explain parts of the puzzles mentioned above, namely the questions of sovereignty for IR scholars and the treatment of institutions and of the content of policy for CPE scholars (cf. Caporaso,

Table 1: A State $v$. Non-state Continuum

\begin{tabular}{llc}
\hline & International Relations & Comparative Political Economy \\
\hline State & Intergovernmentalism & Domestic politics \\
Non-state & Neofunctionalism & Experts/ideas \\
\hline
\end{tabular}

Source: Authors' own data.

\footnotetext{
${ }^{1}$ The article uses the term Stability and Growth Pact (SGP), even though that title was adopted only at the Dublin summit in 1996. Before that time the term 'Stability Pact' was used. The SGP in legal terms comprises only Council Regulations 1466/97 and 1467/97, as well as a resolution of the European Council of 16 June 1997 and, following the reform of 2005, Council Regulations 1055/105 and 1056/105. However, the term SGP is commonly used in a way that additionally comprises the Treaty base, i.e. Articles 99 and 104 TEC.

${ }^{2}$ For earlier work on EMU and eclecticism in theoretical understanding, see Verdun (2000a, 2002). 
1996; Risse-Kappen, 1996). The approaches represent the extremes of a 'state versus non-state' continuum as illustrated in Table 1. The non-state approaches typically focus on the role of non-political (e.g. ideational or technocratic) factors, whereas the state perspective centres on conceptions of power-political relations between governmental actors and structures.

Hence, this article examines the case of the SGP through the lenses of these four theoretical approaches to European integration. The aim is to give a thorough and theoretically rich analysis of the case whilst examining the usefulness of the four selected theoretical approaches. The research focuses predominantly on the following actors: national governments, central banks, experts within ministries and central banks, the Monetary Committee (MC) ${ }^{3}$ and the European Commission. The study draws heavily on Germany and France, Germany being the initiator and main mover, France being the most influential force in opposition to Germany (and thereby 'spokesperson' for several others). The adoption of the SGP was conditional on an agreement between France and Germany. ${ }^{4}$ As regards the implementation of the SGP, France and Germany - while no longer holding the same degree of influence over specific outcomes - were still able to shape events according to their national interest.

The structure of the article is as follows. The first four sections analyse the case through each of the four theoretical lenses: intergovernmentalist, domestic politics, neofunctionalist and experts/ideational approaches. In each of these sections the article focuses on the aspect of the case that the respective approach discusses best and reflects on where the approach falls short. The final section concludes with a plea for eclecticism in the theoretical appraisal of European integration.

\footnotetext{
${ }^{3}$ Since the creation of EMU, the Monetary Committee has been renamed the Economic and Financial Committee (EFC); the Monetary Committee consisted of representatives of the central banks and of Member States (mostly ministries of finance).

${ }^{4}$ Of course all Member States played an important role one way or another. However, a complete discussion of their contribution is beyond the scope of this article. As part of a larger research project empirical data were systematically collected on all Member States (through the use of questionnaires). One of the results is that actors agree that Germany and France were the two crucial countries. Furthermore, 40 face-to-face interviews were held with key informants based on a semi-structured set of ten questions. The persons interviewed included political actors at ministerial and state secretarial level and officials in the ministries of finance, as well as in the central banks of Germany, France and the Netherlands, officials of the European Central Bank, the European Commission, former as well as present members of the MC (now the EFC), and a number of outside experts who have been closely following the developments of the SGP. The study also draws on a variety of other sources: media coverage of the SGP, internal memos, formal public documents, and academic analyses (for an unpublished draft version, please see Heipertz and Verdun, 2004b).
} 


\section{States, Intergovernmentalism and Negotiating the SGP}

An intergovernmentalist explanation of the SGP focuses on the role of Member State governments and emphasizes their aim to secure national interests. Drawing on intergovernmentalist and realist analyses of EMU (Garrett, 1994; Grieco, 1995; Moravcsik, 1998), one can identify Germany and France as the two most important actors who dominated the negotiations and on occasion even determined the crucial features of the outcome between themselves. ${ }^{5}$ Germany held an asymmetrically strong power position on this issue due to the fact that it was giving up de facto monetary leadership. On this basis the SGP was declared of crucial national interest in Germany. France was not only the obvious 'other' major country, but can be seen as representing the positions (i.e. reservations) of a number of other countries. Therefore, the Franco-German exchange is at times equivalent to a sub-set of the negotiations. ${ }^{6}$

Germany's interests consisted of trying to reduce the chance of having excessive deficits in EMU. Its strategies were first, to obtain an international treaty, dubbed a 'fiscal Schengen'. That proving impossible, Germany aimed for strengthening the existing provisions in the Maastricht Treaty. In particular, the German negotiators sought to obtain numerical definitions of a 'severe recession', automatic financial sanctions, and a short time-frame for the application of the excessive deficit procedure (EDP). They thereby wanted to reduce radically the scope for political discretion within the system. The French government's interests consisted of keeping EMU on track, while retaining as much political leverage as possible. The strategies to obtain this leverage were to accommodate some of the German concerns in principle, whilst aiming at largely maintaining the degree of imprecision present in the Maastricht Treaty.

For intergovernmentalists, the relevant mechanism of decision-making on these matters is an institutionalized form of inter-state bargaining. It takes place predominantly in two arenas, namely at the European Council meetings of the heads of state and government (summits) and at Ecofin Council meetings.

\section{The European Council}

Having received the first Ecofin report on the SGP, the Florence European Council in June 1996 generally endorsed proposals contained in it. However,

\footnotetext{
${ }^{5}$ This assumption was checked in interviews and a question posed in the questionnaire (Q21). The interviewees/respondents agreed that these Member States were the most important on this matter. Note, however, that the Commission and the Bundesbank were also seen as important actors.

${ }^{6} C^{\prime}$ 'est un problème franco-allemand ... Mettez-vous d'accord entre vous et nous accepterons votre solution ('It is a franco-german problem ... Agree between yourselves and we will accept your solution.') (Delegation member of the Dublin summit, quoted in Milesi, 1998, p. 145).
} 
there was a first instance of disagreement on open issues: the automatic sanction mechanism, the size of the financial sanctions, and the question of how to define 'exceptional circumstances' under which it would be permitted to run a deficit over 3 per cent. These issues were all eventually settled at lower levels of decision-making, except the issue of what constitutes a 'severe recession' as the main category of an 'exceptional circumstance'. ${ }^{7}$ As the 12-13 December 1996 Dublin Ecofin Council was unable to define the lower boundary of the definition, the final deal was struck personally between the German Chancellor and the French President. Kohl and Chirac met at 0.75 per cent, right in the middle of the points defended by their respective finance ministers. The 0.75 compromise is of interest to an intergovernmental analysis in that it shows the power-political struggle that took place. The choice of 0.5 or 1.0 was not made on economic grounds. The matter, though seemingly technical, became highly symbolical and contentious and ended in a political compromise to ensure that neither side risked losing face. The SGP was finally endorsed by the Amsterdam European Council in June 1997 (after a change of government in France). The package deal in Amsterdam consisted of the incoming French Prime Minister Jospin accepting the SGP whilst Kohl agreed to the inclusion of an employment chapter in the Treaty and the inauguration of a euro area meeting of ministers of finance, later the 'Eurogroup'.

\section{The Ecofin Council}

Waigel's proposal was informally discussed bilaterally as well as in the Ecofin Council months before it was officially tabled in December 1995. There was broad agreement on the principle to strengthen the budgetary regime as defined by the Maastricht Treaty, but strict opposition to the idea of an intergovernmental treaty that would imply automatic sanctions. Most countries were concerned that the German move in reality was designed to erect additional barriers to entry into monetary union beyond the convergence criteria (Stark, 2001). At an early stage Waigel therefore endorsed the principle of developing the project in the form of secondary legislation that would be based on the Maastricht Treaty, which meant that EMU would not be renegotiated. By dropping one of his initial demands, he obtained agreement on initiating secondary legislation along the lines of his proposal. The restrictions and contingencies of the

\footnotetext{
${ }^{7}$ The compromise solution to the question of how to define a 'severe recession' became known as the 'Wicks box' (named after the MC chairman). It was to have upper and lower boundaries in which Ecofin would have discretion to decide whether the recession was 'severe'. There was agreement on the upper boundary (a GDP contraction by 2 per cent or more), but the lower boundary had not yet been agreed on. It lay somewhere between 0.5 per cent (the French preference) and 1.0 per cent (the German preference).

${ }^{8}$ Milesi (1998) and a participant at the Amsterdam summit, interview with the authors, 10 December 2003. Note that all interviewees and respondents to the questionnaire agree with this analysis: Q34 'The renaming from 'Stability Pact' to 'Stability and Growth Pact' was a cosmetic concession to France' (true/false).
} 
Maastricht framework had thereby become determining factors in designing the SGP.

Based on the work of the MC, Ecofin presented an interim report to the European Council in Florence which defined the 3 per cent reference value of the Maastricht Treaty as an absolute ceiling that was to be secured through sanctions unless exceptional circumstances prevailed. It restated the aim of budgetary balance in the medium term. The interim report also announced the design of a preventive surveillance mechanism and resolved to amend the structure of the EDP as laid out in the Treaty with the aim of speeding up the decision-making sequence. The open questions were sent back to the MC.

Waigel increased the stakes through conducting another round of bilateral talks on the need to achieve an SGP if Germany was to proceed with EMU. An informal Ecofin meeting in Dublin on 20-22 September 1996 failed to make progress beyond agreement in principle. Three major issues were still unresolved: firstly, a mechanism for the automatic imposition of sanctions; secondly, the definition of a 'severe recession' that would constitute an exemption from the definition of an excessive deficit; and, thirdly, the size of the financial fines. Each time the Germans wanted stricter rules, whereas the French preferred keeping more political lenience in the system.

The Ecofin meeting in the first week of December 1996 brought agreement on the size of the sanctions as well as on the time-frame for the EDP. However, to discuss the remaining issues an additional Ecofin took place in parallel to the European Council in Dublin on 12-13 December 1996. The question of how to secure a self-commitment of the discretionary Council that would ensure 'quasi-automatic' sanctions and how to define 'severe recession' as an exemption from the definition of excessive deficits remained unclear. Furthermore, France had developed a growing preference for obtaining some concession that would signal that stability would not come at the expense of economic growth, which is why the word 'growth' was added to the title of the Pact.

At this later Ecofin meeting Germany demanded a strict, numerical definition of 'severe recession' without Council discretion on the implementation of the EDP. Other Member States wanted either a looser definition or Council discretion. The objection to the German position was that sovereignty should not be eroded further (Stark, 2001). Germany accepted that the self-commitment be framed in a legally non-binding resolution rather than a regulation, but insisted on a quantitative and unambiguous definition of 'severe recession'. The talks were interrupted for bilateral meetings between the French and German ministers of finance. At the very critical stand-off in Dublin, virtually any Franco-German compromise was sure to find acceptance within the entire group of Ecofin ministers who simply wanted a result (which eventually 
happened, as was already referred to above, with Kohl and Chirac settling the issue at 0.75 per cent).

In the end the German government succeeded in a number of areas. It secured the strengthening of the provisions on budgetary deficits laid out in the Maastricht Treaty. It increased the likelihood of sanctions, shortened the timeline to their application and achieved a numerical definition of a recession that would warrant deficits beyond 3 per cent. However, it had to make substantial concessions in the form of maintaining ultimate political discretion for Ecofin. With the benefit of hindsight, one can argue that neither France nor Germany thought that a majority of Ecofin ministers in the Council would try to circumvent the rules - as eventually occurred on 25 November 2003. Nor less did anybody at the time expect that the authors of the rules would be the first to breach them.

Turning to that controversial Ecofin decision to hold the SGP in abeyance, the intergovernmental approach would offer the following analysis. The German federal government did not want to be punished for its budgetary deficit and did not want to move closer to having sanctions imposed. In the short run, the EDP would have forced the German government to make further budgetary cuts during a highly protracted domestic situation. Schröder's Social-Democratic government judged that it was in its immediate interest to suspend the procedure. The French were in support of the Germans, partly due to a principled objection to a strict SGP, and partly because they also welcomed stopping the process that brought possible sanctions closer. Together, the two countries dominated the Ecofin decisions and orchestrated a blocking coalition against the Commission proposal to advance the procedure. The governments of Austria, Finland, the Netherlands and Spain were opposed to the Franco-German move, but were unable to mount a sufficiently large opposition in support of the Commission. ${ }^{9}$

Wrapping up the intergovernmental analysis, one sees that the origins and the creation of the SGP underline the importance of relative power of the Member States, showing how their preferences shape the outcome. The approach focuses on the European Council and the Ecofin Council as arenas where these decisions are settled. The intergovernmental approach serves to clarify the interaction between the most powerful actors at this highest level of decision-making. For the more subtle issues, the details, as well as for an understanding of the origins of the SGP, different approaches should be adopted, such as a domestic politics approach, to which the article now turns.

\footnotetext{
${ }^{9}$ Official of the Dutch Ministry of Finance, The Hague, 1 December 2003, interview with the authors. 


\section{Opening the Box: Domestic Politics and the SGP}

A domestic politics approach scrutinizes the internal situation of the relevant governments in their respective countries: here, Germany and France. Based on the studies that incorporate a domestic politics perspective of EMU (Dyson and Featherstone, 1996; Martin, 1994; McNamara, 1994; Sandholtz, 1993; Young, 1999) important strong domestic actors can be identified: above all, political parties (in government and opposition) and the central bank. Other actors (parliaments, trade unions, etc.) were influential in EMU and the SGP only insofar as they succeeded in influencing public opinion and national governments.

Besides the federal government, the relevant German domestic actors in the creation of the SGP were the Bundesbank and the Social Democratic Party (SPD), which was in opposition at the time. The interest of the government was to hold on to power while achieving EMU as a major advancement of European integration despite mounting public resistance. The goal of the German opposition party was to undermine the government through stirring up public opinion with the image of an unsound EMU. The aim of the Bundesbank was to improve the stability orientation of EMU by strengthening its fiscal regime (Heipertz, 2001). ${ }^{10}$

The interest of the French government was to hold on to power while achieving EMU as a way to rein in the monetary rule of the Bundesbank and at the same time acquire a global reserve currency. The interest of the French opposition parties was to undermine the government through suggesting to the public that EMU amounted to a 'German dictate' on fiscal rigour that would worsen the unemployment situation.

The Bundesbank had been exerting pressure to strengthen the fiscal provisions of EMU since the adoption of the Maastricht Treaty (Deutsche Bundesbank, 1992). It enjoyed considerable public prestige in Germany and traditionally had a strong voice on economic policy. There were three reasons why Bundesbank criticism of the Maastricht Treaty was particularly influential. The first is the 1993 verdict of the German Constitutional Court, which stated that the Maastricht Treaty was constitutional as long as EMU did not endanger economic stability (BVerfG 89, 155, 12 October 1993). Second, the Bundesbank had a strong influence on public opinion. Third, the bank was to be consulted in 1998 on the European Council's selection of countries that were to enter stage three of EMU in 1999. A strengthened fiscal regime would make it easier for the Bundesbank to accept Belgium and Italy in the common currency.

\footnotetext{
${ }^{10}$ We do not subscribe to the view that the aim of the Bundesbank was to jeopardize the EMU project altogether.

(C) 2005 The Author(s)

Journal compilation (C) 2005 Blackwell Publishing Ltd
} 
The public debate on additional demands for strict rules that surfaced in Germany in 1995 was strategically engineered by the Bundesbank via a federal banking association. ${ }^{11}$ The debate picked up in the course of 1995 and became part of the larger theme of growing public resentment in Germany against EMU. ${ }^{12}$ The opposition party SPD tried to appropriate the topic in the context of the parliamentary debate on the annual budgetary law (Scharping, 1995). Finance Minister Theo Waigel experienced additional pressure within his own CSU party. Bavarian Prime Minister Edmund Stoiber contended with Waigel on CSU leadership and was running on an anti-EMU platform (Frankfurter Allgemeine Zeitung, 4 November 1995) .

The combined effect of political pressure from within the CSU and from the SPD opposition had built up such momentum that the SGP initiative was urgently needed as an excursion for the beleaguered Kohl government. The escalation explains the speed with which Waigel's services had to produce the text of his initiative. The deliberations had been going on informally for months, but the first actual policy document was written within a couple of weeks, partially on the basis of an academic discussion paper (Lehment and Scheide, 1995). A shorter and more concrete English version of the proposal was faxed to Ecofin ministers on the eve of Waigel's appearance in the Bundestag. ${ }^{13}$ Hence, in order to understand the emergence and timing of Waigel's initiative in November 1995, one needs to place it in the context of the party political dynamics in Germany at the time. The German government turned to amending EMU in a way that satisfied domestic needs.

The sway of domestic politics on the SGP in Germany is paralleled, albeit to a lesser degree, by the influence that the French domestic electoral cycle had on the negotiations. President Chirac based his political platform on the concept of une autre politique which implied moving away from the restrictive stance associated with Edouard Balladur. However, he had his Prime Minister Alain Juppé de facto retain the strict policies pursued before, also in view of meeting the convergence criteria by the 1997 deadline. The public felt betrayed. In addition, the government was confronted with low growth and rising unemployment. The public identified the unemployment problem as being caused by the conservative government's stance on fiscal austerity and structural reform; projects that in the public eye were associated with EMU. Rather than being seen as giving in to a German dictate on fiscal discipline, the

${ }^{11}$ Handelsblatt, 9 May 1995, and telephone conversation with an official of the Bundesverband der Volksbanken und Raiffeisenkassen, 4 November 2003.

${ }^{12}$ Sixty-five per cent of the German public was opposed to a single currency in the first half of 1995 (Commission, 1995). This figure is confirmed by a German study, where 67 per cent of the respondents were opposed to EMU in March 1995 (Allensbacher Archiv, 1995).

${ }^{13}$ Officials in the German Ministry of Finance, interviews with the authors, 19 and 23 June 2003.

(c) 2005 The Author(s)

Journal compilation (C) 2005 Blackwell Publishing Ltd 
French government attempted to portray the SGP as an instrument for growth. This is why it was keen to include the word 'growth' in the Stability Pact.

The accumulated effects of the austerity measures would be felt most in 1998, the year of the next general elections. In order to pre-empt this situation, and given the weak state of the socialist party, Chirac decided to hold early elections. An unanticipated change of government, however, took place in June 1997. The incoming Prime Minister, Lionel Jospin, had been voted into office on a platform of reviving growth and boosting employment at the expense of fiscal rigour. Jospin had also promised to renegotiate the SGP and to reverse the 'ultraliberal excesses of EMU' (Agence France Presse, 30 May 1997). The new French government hinted it might veto the creation of the SGP - it was obviously important to obtain some bargaining successes that could be 'sold' domestically. Germany signalled that touching the SGP compromise would cause a major disruption of the EMU process. France retreated and instead requested additional measures that would embed the SGP in a growth-oriented framework. It proposed to institutionalize an informal meeting of EMU ministers of finance (which later became the Eurogroup). In addition, the government obtained (a largely cosmetic) concession in the form of the employment chapter in the Amsterdam Treaty. Just as in changing the name of the Pact, this minor triumph was portrayed to the domestic audience as a considerable bargaining success.

In sum, the German government achieved its aim of having some kind of stability agreement adopted that would appease the Bundesbank and prevent EMU from being derailed through public resentment. The SGP represented a solution that from its point of view constituted only the absolute minimum requirements for accepting a large group of countries (which would include Belgium and Italy) into stage three of EMU (Deutsche Bundesbank,1998). It also pre-empted the SPD from appropriating EMU for electoral purposes.

The conservative French government did not manage to hold on to power in 1997, partially because the opposition succeeded in portraying it as being subservient to excessive German demands for fiscal rigour. However, the conservative and socialist governments in turn did remove the final obstacle on the way to EMU, the long-standing strategic priority of French politics in Europe.

As stated above, the SGP was not applied to the letter. In 2001, the Council failed to issue early warnings to Germany and Portugal. The explanation is again one of German domestic politics. Chancellor Gerhard Schröder feared the negative effect that a 'blue letter' from Brussels would have in the approaching election. A domestic politics approach also sheds light on the decision on 25 November 2003 to suspend the EDP. In both Germany and France, the governments had made promises to the electorate that were not in line with the SGP 
- predominantly tax cuts. Having broken his promises on tax cuts before, Chirac this time decided to go ahead, arguing that they were a necessary complement to pension reform. Schröder's already difficult domestic situation deteriorated in the autumn of 2003, as he was also implementing major structural reforms (in the areas of taxation, health, pensions and labour markets) against growing public unrest. ${ }^{14}$ The tax cuts, as well as the reform measures, were planned to be financed partially through a larger deficit and partially through cuts in subsidies - both of which also had to be accepted by the opposition. In this situation, the government found it impossible to accept further cuts from Brussels, notably at a time when the Commission was putting forward proposals for an increase in the EU budget. A strict application of the SGP in November 2003 would have implied a loss of face domestically and put oil on the fire of the opposition. Potential sanctions could have eventually become a concrete possibility in 2006 - which would have been an election year.

Summarizing, a domestic politics approach explains a number of important moments in which internal political dynamics played a crucial role in shaping the origins as well as the application of the SGP. It allows us to understand the German motivation and particularly the timing of the SGP initiative as a reaction to the opposition's capitalizing on criticism from the Bundesbank and negative public opinion. The approach also explains why the Bundesbank (via public opinion) played an important role in the process. The domestic situation of the French government explains the emphasis on rhetorical references to growth (especially in the title 'Stability and Growth Pact') and the linkage of the SGP to the employment chapter in the Treaty, as well as the idea of creating a Eurogroup in the future. The fact of obtaining concessions in a domestically pertinent area is crucial, not so much the actual content of those concessions. The domestic politics of Germany in the autumn of 2003 largely explains that country's willingness to spearhead a blocking coalition against the EDP. The degree to which a domestic issue becomes important at the European level seems to be a function of the (relative) power of the country and the domestic salience of the issue (which includes the relative power of the domestic actors). Yet the approach falls short of a complete explanation of the SGP. The following section will take up the idea that the Pact was designed in such a way that it would address the functional implications of the Treaty.

\footnotetext{
${ }^{14}$ The constitutional design of the German Federal Republic implies that he needed to co-operate with the political opposition, which had a majority in the second chamber and could thereby veto his reform agenda (see Scharpf, 1988, for an account of the 'decision trap' in German federalism).
} 


\section{A Functional Logic behind the SGP}

A neofunctionalist approach puts the analytical emphasis on EMU features and intrinsic reasons for hardening the fiscal regime. These reasons exist independently of national interests or the role of domestic actors. The relevant actors now are supranational institutions such as the Commission. Socialization takes place in these bodies, which allows their members to work beyond the lowest common denominator that a mere intergovernmental bargaining would envisage. The Commission played a considerable role and successfully pursued its own (functional) agenda to turn the SGP into a device for economic policy co-ordination geared towards a target of budgetary balance.

'Spill-over' is the neofunctionalist mechanism for integration. It implies the extension of co-operation into neighbouring fields as a natural consequence of integrating a particular policy area and corresponds to what the first Commission President Walter Hallstein (1979) called Sachlogik. For the purpose of the SGP the two most important forms of spill-over are functional and political. The former was prevalent in the form of the economic implications of EMU, as well as through the legal framework of Maastricht. Also political spill-over was implicitly present. If one advances integrative measures in the area of budgetary policies, one should be willing to transfer some sovereignty to a new supranational institution or at least subscribe to rules at the European level.

\section{Economic Spill-over}

Installing a centralized monetary policy for different countries is bound to have strong spill-over effects into neighbouring fields of economic policy. It is factually impossible to supranationalize monetary policy and leave the fiscal regime unchanged as if exchange rates were still present and flexible. The effects and requirements of monetary union on fiscal policy have been discussed in the economics literature. The three major issues to be addressed in the context of EMU were: firstly, precautions against negative externalities; secondly, safeguards for the independence of the ECB; and, thirdly, provisions for economic policy co-ordination. There was a widely shared agreement that the Maastricht Treaty was insufficient on these issues. ${ }^{15}$ In this sense, Waigel's initiative met an existing demand for additional legislation.

EMU was seen as giving rise to negative fiscal externalities and worsening existing ones. The assumption at the time was that budgetary interdependence would grow with integration and dramatically so with monetary union. The most prominent worry corresponded to the experience of fiscal spill-overs caused by German reunification. A bond-financed increase in government spending would

${ }^{15}$ Q20: 'The Treaty was incomplete for running EMU successfully' (true/false? Three-quarters chose 'true').

(C) 2005 The Author(s)

Journal compilation (c) 2005 Blackwell Publishing Ltd 
cause the money supply in the euro area to rise, thereby fuelling inflationary pressures. In response, the ECB would be forced to increase interest rates, depressing investment and consumption. A higher interest rate would cause the single currency to appreciate and the trade balance to deteriorate.

Another EMU-induced externality effect is that national exchange rates have been abandoned. Fiscal profligacy before EMU would have had a depreciating effect on the national currency in question, contributing to higher rates of inflation and interest. Once countries join the euro, however, this disciplinary effect is spread out over the entire currency area. The impact on the initial culprit is thereby reduced, while the effect is shared by all participating Member States. By suspending the disciplinary effect on national authorities, EMU hence aggravates an already existing deficit bias of public finance and encourages free-riding (Beetsma, 1999).

Another concern was that excessive deficits could undermine the political independence of the ECB, despite the no-bail out clause in the Treaty (Article 101). In fact, the almost complete reduction of risk premia on government bonds of high-debt countries in the run-up to stage three of EMU shows that the markets indeed anticipated a bail-out. The SGP hence appeared desirable as a way of 'safeguarding the credibility of ECB independence' (Artis and Winkler, 1997).

A further functional motive behind the SGP is the issue of co-ordinating national economic policies vis-à-vis the ECB's monetary stance (Begg, 2002). The goal of co-ordination is the attainment of an appropriate policy-mix between monetary and fiscal policy, possibly extending to wage policy. The policy mix, i.e. the combined effect of the co-ordinated policy fields, should maximize growth while simultaneously preserving price stability. The importance of coordination is increased if there are asymmetric shocks and divergence between the participating economies.

The SGP as originally proposed by Waigel was not intended as an additional instrument for policy co-ordination. However, the Commission identified the functional need for further tools of co-ordination and successfully moulded the Pact into a rudimentary device for that purpose, at least transcending the very limited binding nature of the Broad Economic Policy Guidelines (BEPGs) while retaining compatibility with them. ${ }^{16}$ The crucial advantage of the SGP over the BEPGs and other 'soft' processes was seen to be its 'hard' nature of being backed by sanctions. At least, this seemed partly to close the gap left by the absence of a supranational institution responsible for economic policy co-ordination.

\footnotetext{
${ }^{16}$ The Treaty contains an economic co-ordination framework centred on the BEPG, which belongs to a set of loosely structured and non-enforceable policy co-ordination schemes subsumed under the heading of 'open method of co-ordination'.
} 


\section{Legal Spill-over}

Once Germany accepted that the SGP should be based on the Maastricht Treaty, a whole series of legal consequences ensued that can best be grasped by the concept of functional spill-over in the legal domain. The SGP had to be designed as an instrument of secondary Community law. By definition, secondary legislation has to be consistent with primary law. The relationship between the Treaty establishing the European Community (TEC) and the SGP can be seen as one of path dependence (Pierson, 1996). ${ }^{17}$ However, the functional limitations of the Treaty as discussed above cannot be effectively solved merely through secondary legislation. The regulations cannot qualitatively change the EDP as defined by Article 104. Likewise, the surveillance process does not meet the requirements of strategic co-ordination. Legal spill-over hence limited the degree to which economic spill-over could have an effect.

Nevertheless, the Pact has delivered some 'added value' to the TEC. It has shortened the timeline of the decision sequence, defined the distribution of possible fines (namely among the 'virtuous' Member States), clarified the notion of 'exceptional' and 'temporary' deficits as exemptions from sanctions, introduced an urgency procedure, and enabled the suspension of the EDP. It has also improved the transparency of the procedure: the Council is required to make public its recommendations as well as the voting behaviour of Member States. Finally, the SGP has helped to raise general awareness of the problems of fiscal policy in EMU.

\section{Political Spill-over}

In December 1991 in Maastricht, the heads of state and government decided that rules on budgetary deficits in conjunction with multilateral surveillance would suffice. The fact that they did not transfer powers to a new political body can be seen as lack of political spill-over. In fact, a base for political spill-over was initially proposed by the Germans in the form of a Stability Council dealing with excessive deficits. That part of the proposal was soon withdrawn as it seemed to be possible to mould it into a 'gouvernement économique' (Verdun, $(1996,2003)$ entitled to give instructions to the ECB (which was unacceptable to the Germans).

The November 2003 crisis may suggest that rules are not as effective as a political body would be and that they cannot function in a power vacuum. But perhaps this lesson can only be learnt after experimenting with how rules alone can or cannot govern the complex and divergent economies of 12 countries. If this is true, then the legal spill-over of the Maastricht Treaty has to make way for the consequences of the economic spill-over in the form of a wholesale reform

\footnotetext{
${ }^{17}$ In that sense, also the reform of the Pact in 2005 was path dependent. 
of the fiscal regime. Following this logic, one could argue, speculatively, that political spill-over might emerge. ${ }^{18}$ Yet political reality suggests that concrete transfer of sovereignty to a 'supranational political fiscal body' is unlikely to happen in the near future.

In sum, a functional approach is able to explain parts of the process that led to the creation of the SGP by focusing on the spill-overs and path dependencies in the process. It accounts for the direction of policy-making through functional logic. Yet, legal spill-over defines the limits of economic spill-over. One might argue that the legal dimension of the functionalist logic trumps the economic dimension. Beyond that, the neofunctionalist approach explains how Waigel's initial proposal, which was underdeveloped and focused mainly on securing restrictions on budgetary deficits in stage three of EMU, also triggered regulation on multilateral surveillance and co-ordination. The SGP became firmly embedded in a set of rules as part of the EMU framework. The functionalist logic of (legal) spill-over explains why Member States who had already accepted the rules on budgetary deficits in the Delors Committee and the Maastricht Treaty, then logically continued to accept that 'regime' as the way to move forward when the demand for further policy-making emerged.

However, the neofunctionalist approach, like the other theoretical avenues in isolation, does not account for the entire SGP case. The role of experts and their ideational underpinnings are taken up in the following section.

\section{The SGP and an Expertocratic Approach}

In recent years, European integration theories have been strongly influenced by the emergence of ideas-focused or knowledge-based approaches (Christiansen et al., 1999; Jacobsen, 1995; Parsons, 2002; Radaelli, 1999; Risse, 2000; Verdun 1999). This article proposes to organize in a systematic manner the multitude of 'approaches' that could be captured under this heading. The focus is on the importance of experts, expertise, policy learning, socialization, expert communities, ideas and paradigms. This is labelled an 'expertocratic approach'. ${ }^{19}$ The terms used would be defined as follows. An 'expert' is a person who has 'expertise' over the subject in question, which usually contains complex and technical matter. 'Expertise' is subject knowledge at a 'high' level, resulting

\footnotetext{
${ }^{18}$ Note that the Constitutional Treaty would have moved a little further in this direction.

${ }^{19}$ The rule of experts, from Greek 'kratein' (to rule). The word 'expert' or 'experience' comes from Latin 'experiri' which means 'to try'. Thus those rule who have tried out things and are therefore experienced. Expertocracy is close to, but not identical with, concepts of bureaucracy (Allison, 1971). Bureaucracies consist of experts in hierarchical institutions, such as national ministries or the Commission. The concept of expertocracy is more general and tries to capture expert interaction in hierarchical as well as non-hierarchical situations, such as the MC. The members of the MC are part of hierarchical structures within their national bureaucracies, but assemble in Brussels as a non-hierarchical group. Bureaucratic institutions represent corporate actors, whereas the notion of expertocracy also comprises composite actors (Scharpf, 1997).
} 
from substantial academic training and professional experience. Collective expertise has been gathered over time through trial and error in the policymaking domain (often referred to in the literature as 'policy learning'). When experts collaborate with one another in a professional setting, they become socialized. This 'socialization' process reduces the set of acceptable ideas and behaviour - it makes for small and exclusive 'expert communities'. Within these communities experts have privileged access to information which perpetuates existing group structures and partially explains the dependence of political actors on experts. They process this information through the incorporation of certain 'paradigms' and 'ideas'. 'Paradigms' contain fundamental principles which are upheld over a longer period of time and form the world view of the experts. The paradigm makes up a certain way to see the (economic) world; it is a mentally constructed model of reality (e.g. the 'stability' paradigm). The term 'ideas' is used to describe the variety of ways in which one can 'translate' the paradigm into practice. Note that we envisage that there can be a multitude of ideas on a continuum of possible variations.

In an expertocratic approach, the ideas carried by experts are crucial for understanding the integration process. The actual 'interests' and therefore the 'policy proposals' that are being negotiated should be seen in the light of how they were constructed. What paradigm and which ideas supported those particular interests? Which experts influenced the formulation of these interests? Experts as well as politicians jointly determine the process, building on each others' input. The experts provide the politician with ideas that he/she can use for his/her own political purposes. The politician can also ask the expert to work on a particular policy proposal that will serve the interests of the politician. There is a constant dialectic process between experts and politicians. The expert influences the politician and vice versa. This is particularly strong in the context of the Monetary Committee (MC), where experts usually have a wide margin of discretion to reach consensus within certain boundaries defined by the politicians.

\section{The Stability Paradigm and Policy Learning}

There is one set of economic paradigms that has drawn support in the past three decades: the paradigms of 'neoliberalism', 'monetarism' (Johnson, 1998) and, in its expressive form for the management of economic policy (Henning 1994), the paradigm of 'stability' (Artis and Winkler, 1999) or 'sound money' (Dyson, 2000; Dyson and Featherstone, 1999; Marcussen, 2000; McNamara, 1998). Due to its success, the language and terminology of the stability paradigm ('price stability', 'consolidation', 'trust', 'sustainability' etc.) form the experts' understanding of economic policy and structure the economic 
discourse. It is characterized by the following set of core principles: firstly, the overarching economic parameter to be attained is 'price stability', i.e. low rates of inflation; secondly, price stability is a precondition for growth, not its trade-off, and growth at the expense of price stability only translates into inflation; thirdly, price stability is ensured by a central bank that sets interest rates independently of the (opportunistic, time-inconsistent) political process; finally, the central bank can fulfil its mandate only if other fields of economic policy do not run counter, e.g. in the form of excessive wage bargains or high levels of public debt.

\section{A Peek Inside the Monetary Committee}

The Monetary Committee is a particularly influential advisory committee with a strong internal sense of belonging and its own particular culture (as identified by Hanny and Wessels, 1998; Verdun, 200b; and Westlake, 1995). The socialization that takes place between its members facilitates the canonization of jointly held views on economic and monetary policies in line with previous decisions. Members buy in to the broader framework and specific decisions taken earlier (basing a fiscal rule partially on the convergence criteria, accepting the 3 per cent criterion, etc.) or are socially isolated.

During MC meetings, Commission representatives and national delegations present preliminary policy papers. Through a dialectic process, these initial inputs ${ }^{20}$ converge to a formal legislative proposal (Commission, 1996). MC meetings are generally based on frank interaction. After a tour de table members are informed of each others' starting points. Discussion and exchange of opinions are heard and mutual adjustment of the respective positions takes place. At the end a few options emerge or even boil down to a consensus solution. This is presented for official approval to the Ecofin ministers. Unresolved issues are postponed or referred to Ecofin for active deliberation. The MC aims at consensus decisions; there has been no practice of making decisions by voting. It is seen to play a double role. On the one hand, it takes on the form of a club of professional experts who share a common understanding of EMU. On the other hand, it acts as a group of dependent negotiators who bargain for the positions of their governments.

The MC became involved in the SGP through the request for draft legislation. Most aspects of the SGP and related matters were resolved in the MC: ${ }^{21}$ the medium-term deficit target, rules defining excessive deficits, calculation

\footnotetext{
20 'Towards a Stability Pact' (II/11/96-EN dated 10 January 1996); 'A Stability Pact to Ensure Budgetary Discipline in EMU' (II/163/96-EN dated 18 March 1996); 'Ensuring Budgetary Discipline in Stage Three of EMU' (II/409/96-EN dated 19 July 1996) (for a detailed discussion of the SGP deliberations in the MC, see Costello, 2001).

${ }^{21}$ Most interviewees agreed that as many as 95 per cent of all issues were dealt with in the Monetary Committee.
} 
of the deficit, the general design of a sanctioning mechanism in conjunction with a system of 'early warning', and rules pertaining to Member States who were not in EMU. Other issues were more contentious. The MC referred open questions on the dossiers to Ecofin . The important ones were regarding sanctions, automaticity, exemptions from sanctions, and the definition of a severe economic downturn (see above).

Turning to an evaluation, an expertocratic approach stresses the importance of the stability paradigm within which the experts operate in the MC. Their deliberations represent attempts to translate the paradigm into practice through the presentation of various ideas. These ideas represent expert views on a workable design that fulfils the legal and economic requirements of EMU (discussed in the previous section). Experts determined the range of policy options. They used the existing TEC framework to enhance economic co-ordination by integrating a strengthened multilateral surveillance scheme, as part of the SGP, into the BEPGs. The experts had no preference for connecting the fiscal framework with active employment policies as, for example, the new French socialist Prime Minster Lionel Jospin demanded in 1997. An expertocratic approach is a useful theoretical lens to tease out core elements of the SGP and therefore the crucial contribution of the Monetary Committee. As was seen above, other aspects of the SGP's origins and application are better explained with other approaches.

\section{Conclusions: Implications for European Integration Theory}

This article asked the question, how can the most relevant approaches of European integration theory explain the creation of the SGP and its (non-) application? By looking at this question through four theoretical lenses, the article answers the question, but also broadens the understanding of European integration phenomena more generally. What was the outcome?

An intergovernmental approach expects that Member State governments determine the negotiations in the light of their interests. They succeed in doing so depending on their power and on how credibly they convey their determination to achieve a result close to their interests. This was found to be true insofar as the SGP is the outcome of a bargain between sovereign states. Those instances that were of a highly controversial nature and became 'political' had to be bargained and the results often reflected the power constellation behind national interests.

From the perspective of a domestic politics approach, the expectation was that the domestic situation of a government plays an important role in the creation of the SGP. Indeed, the German government's motivation to create a Stability Pact can be traced back to a need to sell monetary union to an 
increasingly EMU-sceptic domestic audience and to appease the Bundesbank. The French government gained cosmetic concessions in order to assure its domestic constituency. Likewise, the suspension of the SGP in November 2003 can be traced back to domestic considerations of the German government. Hence domestic politics often explains the timing of political initiatives and the degree of salience that is attached to them, i.e. the level to which the issue becomes 'political'.

A neofunctionalist view presumed that the functional implications of EMU require further economic co-ordination. Conversely, the Maastricht Treaty entails legal restrictions on integration in this area, which makes a rules-based approach most attractive. Evidence was indeed found for the presence of this type of tension between two opposing functional logics. It was no surprise to any informed actor at the time that some kind of policy initiative in this field would come after stage two of EMU had started. Hence, neofunctionalism explains the type of policy initiative as well as its framework and direction, given the policy problem from which it originated.

Lastly, focusing on ideas and experts entailed that the realm of acceptable solutions is predetermined by the ideas of experts, who subscribe to a dominant paradigm on economic policy. Changes in these ideas occur through policy learning and exchanges, while the principles of the paradigm remain untouched. The empirical results based on interviews and completed questionnaires strongly confirm this expectation. Experts and ideas explain the actual content of the policy-making process.

In the light of ongoing discussions in the political science discipline about the usefulness of theories, one should try to find the most suitable approach(es) for the case at hand. If the case is of a 'macro' nature, in the sense that there are various dimensions to the issue under discussion, then eclecticism seems warranted. Arguing against the insights obtained through another approach might not be helpful. One single theoretical approach would be overburdened with the task of accounting comprehensively for a complex policy process. If the subject of scientific enquiry is indeed to understand the broader dimension of a policy process rather than for theoretical purposes merely focusing on the outcome or a particular aspect of the process, then eclecticism represents the right methodological choice as a way of trading depth for breadth of analysis.

In conclusion, the Stability and Growth Pact represents an interesting case in which budgetary policy is subjected to European integration through the imposition of rules. Several factors together form an explanation of the policy process behind this outcome: intergovernmental bargaining, domestic politics, functional logic, and the role of experts and ideas. Being eclectic on theoretical avenues has offered an opportunity to think about these matters in a broad perspective. An eclectic analysis of the 2005 reform of the SGP, as well as of 
the implementation of the revised rules, appears to be the logical next step in the intellectual appraisal of governance in EMU.

Correspondence:

Martin Heipertz

International and European Relations

European Central Bank

Postfach 160319

D-60066 Frankfurt am Main, Germany

email: martin.heipertz@ecb.int

\author{
Amy Verdun \\ Department of Political Science \\ University of Victoria \\ PO Box 3050 Victoria BC \\ Canada V8W 3P5 \\ email: averdun@uvic.ca
}

\title{
References
}

Allensbacher Archiv (1995) 'IfD - Umfragen 6013'. Institut für Demoskopie, Allensbach.

Allison, G. (1971) Essence of Decision - Explaining the Cuban Missile Crisis (Boston: Little).

Artis, M.J. and Winkler. B. (1997) 'The Stability Pact: Safeguarding the Credibility of the European Central Bank.' CEPR Discussion Paper 1688.

Artis, M.J. and Winkler, B. (1999) 'The Stability Pact: Trading off Flexibility for Credibility?' In Hughes Hallett, A., Hutchison, M.M. and Jensen, S.E.H. (eds) Fiscal Aspects of European Monetary Integration (New York: Cambridge University Press).

Beetsma, R.M.W. J. (1999) 'The Stability and Growth Pact in a Model with Politically Induced Deficit Biases'. In Hughes Hallett, A., Hutchison, M.M. and Jensen, S.E.H. (eds) Fiscal Aspects of European Monetary Integration (New York: Cambridge University Press).

Begg, I. (ed.) (2002) Europe: Government and Money; Running EMU: The Challenges of Policy Co-ordination (London: Federal Trust).

Bulmer, S. (1983) 'Domestic Politics and European Community Policy-Making.' Journal of Common Market Studies, Vol. 21, No. 4, pp. 349-63.

Caporaso, J. (1996) 'The European Union and Forms of State: Westphalian, Regulatory or Post-modern'. Journal of Common Market Studies, Vol. 34, No. 1, pp. 29-52.

Christiansen, T., Jørgensen, K-E. and Wiener, A. (1999) 'The Social Construction of Europe'. Journal of European Public Policy, Vol. 6, No. 4, pp. 528-44.

Commission of the European Communities (1995) 'Europinion No. 5'. Available at «http://www.europa.eu.int/comm/public_opinion/archives/europinion_cts/eo5/ eo5_en.htm».

Commission of the European Communities (1996) 'Stability Pact for Ensuring Budgetary Discipline in Stage Three of EMU'. Agence Europe. Europe Documents.

Costello, D. (2001) 'The SGP: How did we get there?'. In Brunila, A., Buti, M. and Franco, D. (eds) The Stability and Growth Pact: The Architecture of Fiscal Policy in EMU (Basingstoke/New York: Palgrave). 
Deutsche Bundesbank (1992) 'Stellungnahme des Zentralbankrats: Die Beschlüsse von Maastricht zur Europäischen Wirtschafts- und Währungsunion'. Monatsbericht, $53 \mathrm{pp}$.

Deutsche Bundesbank (1998) 'Stellungnahme des Zentralbankrates zur Konvergenzlage in der Europäischen Union im Hinblick auf die dritte Stufe der Wirtschafts- und Währungsunion'. Monatsbericht, April.

Dyson, K.H.F. (2000) The Politics of the Euro-zone: Stability or Breakdown? (Oxford/New York: Oxford University Press).

Dyson, K.H.F. and Featherstone, K. (1996) ‘Italy and EMU as Vincolo Esterno’. Journal of South European Society and Politics, Vol. 2, No. 3, pp. 272-99.

Dyson, K.H.F. and Featherstone, K. (1999) The Road to Maastricht: Negotiating Economic and Monetary Union (Oxford/New York: Oxford University Press).

Garrett, G. (1994) 'The Politics of Maastricht'. In Eichengreen, B.J. and Frieden, J.A. (eds) The Political Economy of European Monetary Unification (Boulder, CO: Westview).

Grieco, J.M. (1995) 'The Maastricht Treaty, Economic and Monetary Union and the Neorealist Research Programme'. Review of International Studies, Vol. 21, No. 1, pp. 21-40.

Haas, E.B. (1964) Beyond the Nation-State. Political, Social, and Economic Forces 1950-57 (Stanford: Stanford University Press).

Haas, P.M. (1992) 'Introduction: Epistemic Communities and International Policy Co-ordination'. International Organization, Vol. 46, No. 1, pp. 1-35.

Hallstein, W. (1979) Die Europäische Gemeinschaft (Düsseldorf/Wien: EconVerlag.

Hanny, B. and Wessels,W. (1998) 'The Monetary Committee: Significant though not Typical Case'. In van Schendelen, M.P.C.M. (ed.) EU Committees as Influential Policymakers (Aldershot: Ashgate).

Heipertz, M. (2001) 'How Strong was the Bundesbank? A Case Study in the Policymaking of German and European Monetary Union'. CEPS Working Document 172, September.

Heipertz, M. and Verdun, A. (2004a) 'The Dog that Would Never Bite? What we can Learn from the Origins of the Stability and Growth Pact'. Journal of European Public Policy, Vol. 11, No. 5, pp. 765-80.

Heipertz, M. and Verdun, A. (2004b) 'Ruling Europe - Theory and Politics of the Stability and Growth Pact'. Unpublished ms, Max Planck Institute for the Study of Societies, available at «http://www.mpi-fg-koeln.mpg.de/people/hz/Dokumente/ hz-av_gesamt.pdf».

Henning, R. (1994) 'Management of Economic Policy in the European Community'. In Harrison, G.J. (ed.) Europe and the United States: Competition and Co-operation in the 1990s (Armonk: Sharpe).

Hix, S. (1994) 'Approaches to the Study of the European Community: The Challenge to Comparative Politics'. West European Politics, Vol. 17, No. 1, pp. 1-30.

Hoffmann, S. (1966) 'Obstinate or Obsolete: The Fate of the Nation-state and the Case of Western Europe?' Daedalus, Vol. 95, No. 3, pp. 862-916. 
Huelshoff, M.G. (1994) 'Domestic Politics and Dynamic Issue Linkages - A Reformulation of Integration Theory'. International Studies Quarterly, Vol. 38, No. 2, pp. 255-79.

Jacobsen, J.K. (1995) 'Much Ado About Ideas: The Cognitive Factor in Economic Policy'. World Politics, No. 47, pp. 283-310.

Johnson, P.A. (1998) The Government of Money: Monetarism in Germany and the United States (Ithaca: Cornell University Press).

Lehment, H. and Scheide, J. (1995) 'Der Fahrplan für die Europäische Währungsunion: Noch erheblicher Handlungs- und Klärungsbedarf'. Kiel Discussion Papers 259.

McNamara, K.R. (1994) 'Economic and Monetary Union: Do Domestic Politics Really Matter?'. Paper Presented at the American Political Science Association Annual Meeting.

McNamara, K.R. (1998) The Currency of Ideas: Monetary Politics in the European Union (Ithaca: Cornell University Press).

Marcussen, M. (2000) Ideas and Elites: The Social Construction of Economic and Monetary Union (Vilborg: Aalborg University Press).

Martin, L.L. (1994) 'International and Domestic Institutions in the EMU Process'. In Eichengreen, B.J. and Frieden, J.A. (eds) The Political Economy of European Monetary Unification (Boulder, CO: Westview).

Martin, L.L. (1995) 'The Influence of National Parliaments on European Integration'. In Eichengreen, B.J., Frieden, J.A. and von Hagen, J. (eds) Politics and Institutions in an Integrated Europe (Berlin: Springer).

Milesi, G. (1998) Le roman de l'euro (Paris: Hachette littératures).

Moravcsik, A. (1998) The Choice for Europe: Social Purpose and State Power from Messina to Maastricht (Ithaca: Cornell University Press).

Parsons, C. (2002) 'Showing Ideas as Causes: The Origins of the European Union'. International Organization, Vol. 56, No. 1, pp. 47-84.

Pierson, P. (1996) 'The Path to European Integration: A Historical Institutionalist Analysis.' Comparative Political Studies, Vol. 29, No. 2, pp. 123-63.

Puetter, U. (2004) 'Governing Informally: The Role of the Eurogroup in EMU and the Stability and Growth Pact'. Journal of European Public Policy, Vol. 11, pp. 854-70.

Radaelli, C.M. (1995) 'The Role of Knowledge in the Policy Process'. Journal of European Public Policy, Vol. 2, No. 2, pp. 159-84.

Radaelli, C.M. (1999) Technocracy in the European Union (London/New York: Longman).

Risse, T. (2000) 'Let's Argue!': Communicative Action in World Politics'. International Organization, Vol. 54, No. 1, pp. 1-40.

Risse-Kappen, T. (1996) 'Exploring the Nature of the Beast: International Relations Theory and Comparative Policy Analysis Meet the European Union'. Journal of Common Market Studies, Vol. 34, No. 1, pp. 53-80.

Sandholtz, W. (1993) 'Choosing Union: Monetary Politics and Maastricht'. International Organization, Vol. 47, No. 1, pp. 1-39. 
Scharpf, F.W. (1988) 'The Joint-Decision Trap - Lessons from German Federalism and European-Integration'. Public Administration, Vol. 66, No. 3, pp. 239-78.

Scharpf, F.W. (1997) Games Real Actors Play: Actor-centered Institutionalism in Policy Research. Theoretical Lenses on Public Policy Series (Boulder/Oxford: HarperCollins/Westview).

Scharping, R. (1995) 'Zweite Lesung zum Haushaltsgesetz 1996'. Bonn, Bundestagsdrucksache 13/67, 8 November.

Schmitter, P. (2004) 'Neofunctionalism'. In Wiener, A. and Diez, T. (eds) European Integration Theory (Oxford/New York: Oxford University Press).

Stark, J. (2001) 'Genesis of a Pact'. In Brunila, A., Buti, M. and Franco, D. (eds) The Stability and Growth Pact: The Architecture of Fiscal Policy in EMU (New York: Palgrave).

Verdun, A. (1996) 'An "Asymmetrical" Economic and Monetary Union in the EU: Perceptions of Monetary Authorities and Social Partners'. Journal of European Integration, Vol. 20, No. 1, pp. 59-81.

Verdun, A. (1999) 'The Role of the Delors Committee in the Creation of EMU: An Epistemic Community?' Journal of European Public Policy, Vol. 6, No. 2), pp. 308-28.

Verdun, A. (2000a) European Responses to Globalization and Financial Market Integration. Perceptions of Economic and Monetary Union in Britain, France and Germany (Basingstoke/New York: Palgrave/St. Martin's Press).

Verdun, A. (2000b) 'Governing by Committee: The Case of the Monetary Committee'. In Christiansen, T. and Kirchner, E. (eds) Committee Governance in the European Union (Manchester: Manchester University Press).

Verdun, A. (2002) 'Merging Neofunctionalism and Intergovernmentalism: Lessons from EMU'. In Verdun, A. (ed.) The Euro: European Integration Theory and Economic and Monetary Union (Boulder: Rowman and Littlefield).

Verdun, A. (2003) 'La nécessité d'un "gouvernement économique" dans une UEM asymétrique. Les préoccupations françaises sont-elles justifiées?'. Politique européenne, No. 10, pp. 11-32.

Westlake, M. (1995) The Council of the European Union (London: Cartermill).

Young, R. (1999) 'The Politics of the Single Currency: Learning the Lessons of Maastricht'. Journal of Common Market Studies, Vol. 37, No. 2, pp. 295-316. 